\title{
A Mini-Review on the Phytochemistry and Pharmacology of the Plant Carica Papaya L. (Caricaceae)
}

\author{
Clement Inkoto Liyongo ${ }^{1}$, Colette Masengo Ashande ${ }^{2}$, Clarisse Falanga Mawi ${ }^{3}$, \\ Blaise Membo wa Mbembo ${ }^{4}$, Jean-Jacques Amogu Domondo ${ }^{5}$, Mahendra Ilmi \\ $\underline{S_{\text {Matondang }}}{ }^{6}$, Jean-Pierre Kayembe Kayembe ${ }^{7}$, Pius Tshimankinda Mpiana ${ }^{8}$, \\ Koto-te-Nyiwa Ngbolua ${ }^{9}$ \\ 1,3,4,5, Department of Biology, Faculty of Science, University of Kinshasa, Democratic Republic of the \\ Congo \\ 2,9Department of Environmental Sciences, University of Gbado-Lite, Gbado-Lite, Democratic Republic of \\ the Congo \\ 'Department of Biotechnology, FBIM, Universiti Sultan Zainal Abidin, Kuala Terengganu, Malaysia \\ ${ }^{7}$ Research Focus Area for Chemical Resource Beneficiation (CRB), Catalysis and Synthesis Research \\ Group, North-West University, Potchefstroom 2522, South Africa \\ ${ }^{8}$ Department of Chemistry, Faculty of Sciences, University of Kinshasa, Kinshasa, Democratic Republic \\ of the Congo \\ Email: jpngbolua@unikin.ac.cd
}

\begin{abstract}
:
Medicinal plant is an important element of indigenous medical systems all over the world. The ethno botany provides a rich resource for natural drug research and development. Carica papaya is used in Traditional Medicine since a long time. Our investigations started by a search of relevant literature on the plant species. Databases such as Science direct, PubMed, Google Scholar and Scopus were used successively to retrieve the articles on C. papaya. The chemical structures of isolates compounds from this plant were drawn using ChemBioDraw Ultra 12.0 software package. Finally, bibliographical references were made using bibliographical software "Mendeley". Results show that the plant C. papaya contains various secondary metabolites, minerals and vitamins. The plant species is reported to possess various pharmacological properties like anti-oxidant, antiinflammatory, antibacterial, anti-diabetic, anti-hyperlipidemic, larvicidal effects, etc. These pharmacological activities could due to the presence of various phytochemicals present in this plant species. The present review can therefore help inform future scientific research towards the development of novel drugs of relevance from C. papaya to combat various ailments including Sickle cell disease.
\end{abstract}

Keywords:

medicinal plant; carica papay; bioactivity; phytochemicals; phyto-drugs; democratic Republic of the Congo

\section{Introduction}

Medicinal plant is an important element of indigenous medical systems in all over the world. The ethno botany provides a rich resource for natural drug research and development [1]. Natural products have played an important role throughout the world in treating and preventing human diseases [2]. According to the World Health Organization (WHO), 80\% of the population living in developing countries relies on traditional medicine for their primary health care needs [35]. In Democratic Republic of Congo (DRC), medicinal plants represent the key product for both urban and rural populations for their health care needs because the costs of conventional drugs are often unaffordable. These medicinal plants have found to have therapeutic value for fighting against major health problems [6-9]. C. papaya is a tropical tree, native to Central America and 
now widely cultivated in all tropical and sub-tropical regions for its edible fruits and its latex. [10] The medicinal properties of $\mathrm{C}$. papaya are well documented in traditional systems of medicine [11] Many phyto-constituents were identified from different parts of C. papaya like saponnins, alkaloids, flavonoids, phenolic acid, terpenoids, carbohydrates, reducing sugars, phytosterols, cardiac glycosides, tannins and anthraquinnon, amino acids and proteins [12-19]. It possesses as well antioxidant, antimicrobial; ant sickling, anthelminthic, antimalarial, anti-inflammatory, antidiabetic, antipyretic, anti-hyperglycemic activities were reported.

The main aim of the present study was to review the literature on the nutritional value, phytochemistry and pharmacology of Caraca papaya. These data would allow this species to be used as a multifunctional and low toxicity phyto-drug candidate for the management of various diseases.

\section{Research Method}

In this study, our investigations started by a search of relevant literature on the plant species. Databases such as Science direct, PubMed, Google Scholar and Scopus were used successively to retrieve the articles on C. papaya. The chemical structures of isolates compounds from this plant were drawn using ChemBioDraw Ultra 12.0 software package. Finally, bibliographical references were made using bibliographical software "Mendeley".

\section{Results and Discussion}

\subsection{Botany}

Asha et al. [20] reported C. papaya is a polygamous species and it is difficult to identify a plant whether it is male, female or hermaphrodite. It is a tree reaching 3-10 $\mathrm{m}$ in height, with the habit of a palm; the fleshy stem marked by scars where leaves have fallen off, is surmounted by a terminal panache of leaves on long petioles and with 5-7 lobes. Flowers fragrant, trimorphous, usually unisexual-dioeciously, male flowers in lax many-flowered, densely pubescent cymes at the tips of the pendulous, fistular rachis; female flowers large, solitary or in few flowered racemes, with a short thick rachis, fruit a large berry, varying widely in size, elongate to globose with a large central cavity, seeds black, tuberculous and enclosed in a transparent aril. Its flowers are mostly dioeciously and resemble each other until they start to develop sexual organs [21]. The fruit bearing trees are less than 18 month old. The leaves and unripe fruit contain milky juice in which the protein ferment papain is present. The fruit is ripe when it feels soft (like a ripe avocado or a bit softer) and its skin has attained amber to orange hue. The melon-like fruit varies in size and shape, and hangs from short, thick peduncles at the leaf axil.

This species is a large tree-like plant, with a single stem growing with spirally arranged leaves confined to the top of the trunk. The lower trunk is conspicuously scarred where leaves and fruit were borne. The leaves are large, 50-70 centimeters (20-28 in) diameter. The tree of this plant is usually unbranched, unless lopped. They appear on the axils of the leaves, maturing into the large 15-45 centimeters (5.9-18 in) long, 10-30 centimeters (3.9-12 in) diameter fruit.

\subsection{Origin and Geographic Distribution}

The survey of literature reveals that this species is native to Central America, formerly from southern Mexico, and now widely cultivated in all tropical and sub-tropical countries because of its high yield, nutritional value, functional properties, and year-round fruit production, the importance of this crop around the world is undeniable [19, 20, 22, 23] . 


\subsection{Ethnobotany}

In Asia regions, particularly in Pakistan, India and Sri Lanka the green fruit of papaya is used for contraceptive purposes by traditional healers [24]. Krishna et al. [11] reported that C. papaya leaves are being used specifically for fever, beriberi, asthma, colic in India. Other reports in the same country suggest that different parts of C. papaya such fruits, seeds, bark, leaves, roots and latex has been used for treatment of several diseases like jaundice, stomach problem, dengue, blood pressure, wound dressing and snake bite [25, 26]. Amenta et al. [27] reported that latex of C. papaya is employed to treat eczema and psoriasis in Cambodia and Vietnam. The seeds have been used to heal vermifuge, thirst quencher, or pain alleviator [11] In Jamaica, Hewitt et al. [28] reported the ripe fruit has been used as topical ulcer dressings to promote desloughing, granulation, healing, and reducing odor in chronic skin ulcers. C. papaya leaves are used for heal cancer in Australia [29]. In Nigeria, the green fruit has been used for various human and veterinary diseases such as malaria, hypertension, diabetes mellitus, jaundice, intestinal helminthiasis [24].

\subsection{Phytochemistry}

Many phyto-constituents were identified from different parts of C. papaya. Phytochemical screening of C. papaya fruits, leaves and seeds showed various secondary metabolites like saponnins, alkaloids, flavonoids, phenolic acid, terpenoids, carbohydrates, reducing sugars, phytosterols, cardiac glycosides, tannins and anthraquinnon [12-18].

The seeds of this plant contain fatty acids, crude protein, crude fiber, papaya oil, sinigrin, Carpaine, benzylisothiocyanate, benzyl glucosinolate, glucotropacolin, benzylthiourea, hentriacontane, $\beta$-sitosterol, caricin and an enzyme myrosin [20]. The same authors [20] reported that the juice of $\mathrm{C}$. papaya have N-butyric, n-hexanoic and n-octanoic acids, lipids; myristic, palmitic, stearic, linoleic, linolenic and cis-vaccenic and oleic acids. The protein, fat, fiber, carbohydrates, minerals such calcium, phosphorous, iron, vitamin $\mathrm{C}$, thiamine, riboflavin, niacin, and carotene, amino acids, citric and malic acids, volatile compounds including linalool, benzyl isothiocyanate, cis and trans 2, 6-dimethyl-3,6 epoxy-7 octen-2-ol, Alkaloid, $\alpha$-carpaine, benzyl- $\beta$ $\mathrm{D}$ glucoside, 2 -phenylethyl - $\beta$-Dglucoside, 4-hydroxy-phenyl-2 ethyl- $\beta$-D-glucoside and four isomeric malonated benzyl- $\beta$-D-glucosides were identified in Carica papaya fruits. [20, 21] This plant contains proteins and amino acids $[15,19]$. For nutritional value of $100 \mathrm{~g}$ of papaya fruit, Tarun \& Yash [2015] reported the constituents of ripe C. papaya contain: energy (163 ca), fat (0.1 $\mathrm{g})$, minerals $(0.5 \mathrm{~g})$, fibre $(0.8 \mathrm{~g}),(7.2 \mathrm{~g})$, sodium $(3 \mathrm{mg})$, iron $(0.10 \mathrm{~g})$, vitamin A (1 $094 \mathrm{IU}), \mathrm{E}$ $(0.73 \mathrm{mg})$, niacin $(3 \mathrm{mg})$ and water $(89 \%)$.

Table 1. Mineral Composition of C. papaya Leaves Acknowledgements

\begin{tabular}{|c|c|c|c|}
\hline Mineral & Green leaf & Yellow leaf & Brown leaf \\
\hline \multicolumn{4}{|c|}{ Mineral Composition on dry weight basis $(\mathrm{mg} / \mathrm{kg})$} \\
\hline $\mathrm{Ca}$ & 8612.50 & 3762.50 & 4362.50 \\
\hline $\mathrm{Mg}$ & 67.75 & 28.55 & 35.35 \\
\hline $\mathrm{Na}$ & 1782.00 & 567.00 & 324.00 \\
\hline K & 2889.00 & 819.00 & 468.00 \\
\hline $\mathrm{Fe}$ & 90.50 & 147.50 & 79.50 \\
\hline $\mathrm{Mn}$ & 9.50 & 5.00 & 4.50 \\
\hline \multicolumn{4}{|c|}{ Vitamin Compositions on a dry basis $(\mathrm{mg} / 100 \mathrm{~g})$} \\
\hline Vitamin & Green leaf & Yellow leaf & Brown leaf \\
\hline Ascorbic Acid & 16.29 & 9.62 & 11.26 \\
\hline Thiamine & 0.94 & 0.41 & 0.52 \\
\hline Riboflavin & 0.13 & 0.04 & 0.06 \\
\hline
\end{tabular}


Table 2. Proximate, Mineral and Vitamins composition of Carica papaya

\begin{tabular}{|l|l|l|l|l|l|}
\hline $\mathrm{N}^{\circ}$ & Parameters & Values & $\mathrm{N}^{\circ}$ & Parameters & Values \\
\hline 01 & Energy & $179 \mathrm{KJ}(43 \mathrm{Kcal})$ & 15 & Zinc & $0.08 \mathrm{mg}(1 \%)$ \\
\hline 02 & $\begin{array}{l}\text { Carbohydra } \\
\text { tes }\end{array}$ & $10.82 \mathrm{~g}$ & 16 & Lycopene & $1828 \mu \mathrm{g}$ \\
\hline 03 & Sugars & $7.82 \mathrm{~g}$ & 17 & Beta-carotene & $274 \mu \mathrm{g} \mathrm{(3 \% )}$ \\
\hline 04 & $\begin{array}{l}\text { Dietary } \\
\text { fiber }\end{array}$ & $1.7 \mathrm{~g}$ & 18 & Lutein and zeaxanthin & $89 \mu \mathrm{g}$ \\
\hline 05 & Fat & $0.26 \mathrm{~g}$ & 19 & Thiamine (vit. B1) & $0.023 \mathrm{mg} \mathrm{(2 \% )}$ \\
\hline 06 & Protein & $0.47 \mathrm{~g}$ & 20 & Riboflavin (vit. B2) & $0.027 \mathrm{mg} \mathrm{(2 \% )}$ \\
\hline 07 & $\begin{array}{l}\text { Vitamin A } \\
\text { equiv. }\end{array}$ & $47 \mu \mathrm{g}(6 \%)$ & 21 & Niacin (vit. B3) & $0.357 \mathrm{mg} \mathrm{(2 \% )}$ \\
\hline 08 & Calcium & $20 \mathrm{mg} \mathrm{(2 \% )}$ & 22 & Pantothenie acid (B5) & $0.191 \mathrm{mg} \mathrm{(4 \% )}$ \\
\hline 09 & Iron & $0.25 \mathrm{mg} \mathrm{(2 \% )}$ & 23 & Vitamin B6 & $0.38 \mathrm{mg} \mathrm{(3 \% )}$ \\
\hline 10 & Magnesium & $21 \mathrm{mg} \mathrm{(6 \% )}$ & 24 & Folate (Vit. B9) & $38 \mu \mathrm{g} \mathrm{(10 \% )}$ \\
\hline 11 & Manganese & $0.04 \mathrm{mg}(2 \%)$ & 25 & Vitamin C & $62 \mathrm{mg} \mathrm{(75 \% )}$ \\
\hline 12 & Phosphorus & $10 \mathrm{mg}(1 \%)$ & 26 & Vitamin E & $0.3 \mathrm{mg} \mathrm{(2 \% )}$ \\
\hline 13 & Potassium & $182 \mathrm{mg}(4 \%)$ & 27 & Vitamin K & $2.6 \mu \mathrm{g}(2 \%)$ \\
\hline 14 & Sodium & $8 \mathrm{mg}(1 \%)$ & & - & - \\
\hline
\end{tabular}<smiles>CC(C=CC=C(C)C=CC(C)=CC=CC1C(C)CC=CC1(C)C)=CC=CC(C)=CC=CC1C=CC=CC1(C)C</smiles><smiles>CC(=O)CCCC(=O)O</smiles><smiles>C=CC/C(=N\OS(=O)(=O)O)SC1O[C@H](CO)[C@@H](O)[C@H](O)[C@H]1O</smiles>

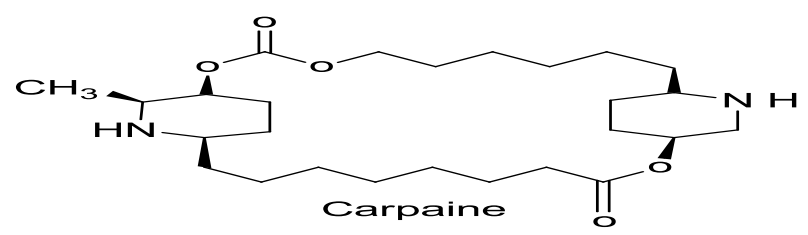

Figure 1. Compounds Isolated from the Parts of Carica papaya 
Table 3. Plant used Part, Extracts, Model System and Biological Properties of Carica papaya

\begin{tabular}{|c|c|c|c|c|}
\hline Plant parts & Extracts & $\begin{array}{l}\text { Biological } \\
\text { Activities }\end{array}$ & Model System & Authors \\
\hline \multirow[t]{5}{*}{ Leaf } & $\begin{array}{l}\text { Methanolic } \\
\text { extract }\end{array}$ & $\begin{array}{l}\text { Antisickling } \\
\text { activity, larvicdial } \\
\text { and pupicidal } \\
\text { activities }\end{array}$ & $\begin{array}{l}\text { Sickle cell, Mosquito } \\
\text { larva (Aedes aegypti) }\end{array}$ & {$[13,30]$} \\
\hline & \multirow[t]{2}{*}{$\begin{array}{l}\text { Aqueous extract, } \\
\text { aqueous and } \\
\text { ethanol extracts }\end{array}$} & $\begin{array}{l}\text { wound healing } \\
\text { and } \\
\text { hasprotective } \\
\text { effects against } \\
\text { gastric damage, } \\
\text { antioxidant } \\
\text { activity, } \\
\text { antimicrobial } \\
\text { activities }\end{array}$ & $\begin{array}{l}\text { Rats, Enterobacteriales } \\
\text { family }\end{array}$ & [31-33] \\
\hline & & $\begin{array}{l}\text { bactericidal } \\
\text { activity }\end{array}$ & Bacteria & [31] \\
\hline & $\begin{array}{c}\text { Ethanol, } \\
\text { methanol, Ethyl } \\
\text { acetate, acetone, } \\
\text { chloroform, } \\
\text { Petroleum ether, } \\
\text { hexane and hot } \\
\text { water extracts }\end{array}$ & $\begin{array}{l}\text { Antibacterial } \\
\text { activity and } \\
\text { Antifungal } \\
\text { activity }\end{array}$ & Bacteria and fungus & [15] \\
\hline & Ethanolic extract & $\begin{array}{c}\text { inflammatory } \\
\text { activity }\end{array}$ & Rats & [34] \\
\hline \multirow[t]{2}{*}{ Roots } & $\begin{array}{l}\text { Aqueous extract, } \\
\text { methanol and } \\
\text { acetone extracts. }\end{array}$ & $\begin{array}{c}\text { antimicrobial } \\
\text { activity, wound } \\
\text { healing activity, } \\
\text { Hypoglycemic } \\
\text { activity }\end{array}$ & Bacteria, Rats, Rats & {$[35-37]$} \\
\hline & Ethanolic extract & $\begin{array}{c}\text { modulating } \\
\text { activity }\end{array}$ & Rats & [38] \\
\hline \multirow[t]{5}{*}{ Seeds } & Aqueous extract & $\begin{array}{l}\text { antioxidant } \\
\text { activity, } \\
\text { anthelmintic } \\
\text { activity }\end{array}$ & $\begin{array}{c}\text { Rats, } \\
\text { helminth(Caenorhabditis } \\
\text { elegans) }\end{array}$ & {$[39,40]$} \\
\hline & - & $\begin{array}{c}\text { antihelminthic } \\
\text { and anti-amoebic } \\
\text { activities }\end{array}$ & children $2-6$ years old & $\overline{[41]}$ \\
\hline & $\begin{array}{l}\text { Chloroform } \\
\text { extract }\end{array}$ & $\begin{array}{l}\text { Spermicidal } \\
\text { activity, } \\
\text { antifertility } \\
\text { activity } \\
\end{array}$ & $\begin{array}{c}\text { rats and rabbits, langur } \\
\text { monkey }\end{array}$ & {$[42,43]$} \\
\hline & $\begin{array}{l}\text { Hexane, acetone, } \\
\text { chloroform, } \\
\text { methanol, } \\
\text { ethanol, water } \\
\end{array}$ & $\begin{array}{l}\text { Antioxidant } \\
\text { activity }\end{array}$ & - & [44] \\
\hline & Acetone extract & Antioxidant & - & [45] \\
\hline
\end{tabular}




\begin{tabular}{|c|c|c|c|c|}
\hline & & activity & & \\
\hline & Ethanolic extract & $\begin{array}{c}\text { molluscicidal } \\
\text { activity }\end{array}$ & Snails & [46] \\
\hline \multirow[t]{3}{*}{ Fruit } & Aqueous extract & $\begin{array}{l}\text { antioxidant and } \\
\text { immunostimulant } \\
\text { activities }\end{array}$ & Rats & [47] \\
\hline & Ethanol extract & $\begin{array}{l}\text { Antifungal } \\
\text { Activity }\end{array}$ & phytopathogenic fungi & [48] \\
\hline & $\begin{array}{c}\text { Ethanol and } \\
\text { aqueous extracts }\end{array}$ & $\begin{array}{l}\text { hepatotoxic } \\
\text { activity }\end{array}$ & - & [49] \\
\hline
\end{tabular}

\subsection{Biological Activities}

\section{a. Anti-amoebic Activity}

The anti-amoebic activity of C. papaya seeds was evaluate against Entamoeba histolytica infection compared with metronidazole by using mice models. The result show that a single oral dose of C. papaya seeds water extracts of up to $(0.1 \mathrm{~mL} / \mathrm{mice} /$ day $)$ reduced parasite appearance in feces and disappear completely at the 8th day compared with metronidazole the cysts parasite continued till 10th day. The histomorphological study findings showed in the group which was given C. papaya seeds the majority of tissue intestine return to normal shape [50]. Okeniyi et al. [41] reported that air-dried C. papaya seeds are efficacious in treating human intestinal parasitosis.

\section{b. Gastro-protective Activity}

Gastro-protective effects of aqueous C. papaya seed extract on ethanol induced gastric ulcer were investigated in male rats. Thirty two male's rats weighing between 180 and $250 \mathrm{~g}$ were randomly divided into four groups. Group 1 served as the negative control (distilled water), groups 2 and 3 received $50 \mathrm{mg} / \mathrm{kg}$ and $100 \mathrm{mg} / \mathrm{kg}$ C. papaya seed extract respectively, while group 4 received $200 \mathrm{mg} / \mathrm{kg}$ cimetidine (positive control). After two weeks, the results showed that the extract protected the gastric mucosa against ethanol effect. C. papaya extract significantly reduced the gastric juice volume and gastric acidity $(\mathrm{p}<0.05)$ in dose dependent manner when compared with the control. The percentage ulcer inhibition was significantly high $(\mathrm{p}<0.05)$ in rats treated with the extract when compared with the control and the effect is similar to that of rats treated with cimetidine.

\section{c. Antibacterial and Antifungal Activities}

Jyotsna et al. [52] demonstrated the antibacterial activity of C. papaya extracts. The results of this study revealed that the aqueous and methanolic extracts of seeds were effective to inhibit the bacterial pathogens but chloroform extract did not show any inhibition against the bacteria. Different solvent extracts of C. papaya were tested against Gram positive (Staphylococcus aureus and Bacillus cereus) and Gram negative (E. coli, P. aeruginosa and Shield Flexner) bacterial strains by observing the zone of inhibition. The ethanol, chloroform and benzene extracts of C. papaya showed activity against bacteria, the chloroform extract of this plant showed stronger activity against E. coli and P. aeruginosa. The ethanol extract showed stronger activity on B. cereus and E. coli. Chloroform extract in bacteria showed a varying degree of inhibition to the growth of tested organism [12].

In another study, Baskaran et al. [15] investigated the antimicrobial activity of various extracts of C. papaya. Their result showed these extracts have antibacteria and antifungal activities. The chloroform extract of $\mathrm{C}$. papaya showed more activity against Micrococcus luteus, zone of diameter $15.17 \pm 0.29 \mathrm{~mm}$ and acetone extract $C$. papaya showed more activity against 
Candida albicans, zone diameter $11.23 \pm 0.25 \mathrm{~mm}$ compared to other solvent extracts. In papaya, absolute ethanolic extract showed highest antibacterial activity [53].

\section{d. Anti-diabetic Activity}

Sobia et al. [54] investigated the antidiabetic activity of the C. papaya leaves extracts in mice. The results of this study indicates that hyperglycemic level in diabetic mice was normalized after administration of various doses $(50,150 \mathrm{and} 300 \mathrm{mg} / \mathrm{kg}$ bw) of ethanolic leaves extracts to diabetic mice. Similarly leaves extracts of C. Papaya have also shown pronounced effects on plasma insulin, triglyceride, and cholesterol and HDL cholesterol levels. The levels of liver enzymes (ALT, AST and ALP), bilirubin and blood cells (Red cells, white cells and platelets) were improved on dose depended manner. It is assumed that biologically active components of papaya leaf extracts are helpful in decreasing secondary complications of diabetes and improved insulin sensitivity to uptake glucose by cells.

\section{e. Anti-hyperglycemic Activity}

Antidiabetic effect of the ethanol extracts of C. papaya on streptozotocin-induced diabetic mice was investigated. The results of this study indicated that there was no significant difference in the body weight of the treated groups when compared to diabetic control. Whereas, there was significant decrease in the blood glucose level of the plant treated groups compared to the diabetic control. Histologically the pancreas of the treated groups indicated significant regeneration of the $\beta$-cells when compared to the diabetic control. The liver tissues of the treated group indicated a reduction in fatty changes and pyknotic nucleus. The kidney tissues of the treated groups indicated significant recovery in the cuboidal tissue. The antidiabetic effect of C. papaya observed in the present study may be due to the presence of these phytochemicals [17].

\section{f. Anti-inflammatory, Antipyretic and Antinociceptive Activities}

Anti-inflammatory, antipyretic and antinociceptive activities of aqueous extract of C. papaya seeds were demonstrated in animal models. These activities were done using 15\% suspension of Brewer'syeast in Wistar rats (Antipyretic activity), using writhing method in mice and tail immersion method in Wistar rats (anti-nociceptive) and done using the xylene-induced ear oedema test and Carrageenan-induced paw oedema (anti-inflammatory activity).

The results showed there was a significant decrease in temperature after 120 mins for both extract groups. For the antinociceptive activity, there was no analgesia with tail immersion test while the writhing test produced $4.5 \%$ and $17.4 \%$ inhibition for groups 3 and 4 respectively. In the Carrageenan-induced paw oedema, the extract test did not have significant effect while the xylene-induced ear oedema test showed inhibitions of $27.72 \%$ and $34.97 \%$ for groups 3 and 4 respectively [55]. Owoyele et al. [34] investigated the anti-inflammatory activity of an ethanolic extract of C. papaya leaves in rats using carrageenan induced paw oedema, cotton pellet granuloma and formaldehyde induced arthritis models. Experimental animals received 25-200 $\mathrm{mg} / \mathrm{Kg}$ (orally) of the extracts or saline (control group) and the reference group received 5 $\mathrm{mg} / \mathrm{Kg}$ of indomethacin. The ulcerogenic activity of the extract was also investigated. The results show that the extracts significantly $(p<0.05)$ reduced paw oedema in the carrageenan test. Likewise the extract produced significant reduction in the amount of granuloma formed from $0.58 \pm 0.07$ to $0.22 \pm 0.03 \mathrm{~g}$. In the formaldehyde arthritis model, the extracts significantly reduced the persistent oedema from the 4 th day to the 10 th day of the investigation.

\section{g. Antisickling Activity}

Imaga et al. [13] examined methanolic leaf extracts of C. papaya for possible in vitro antisickling and membrane-stabilizing activities involving the use of positive ( $\mathrm{p}$-hydroxybenzoic 
acid $5 \mathrm{mg} / \mathrm{mL}$ ) and negative (normal saline) controls for the antisickling experiments and osmotic fragility test on Hbss red blood cells obtained from non-crisis state sickle cell patients. Fragiliograms indicated that the plant extract reduced hemolysis and protected erythrocyte membrane integrity under osmotic stress conditions. Pretreatment of SS cell suspensions with C. papaya leaf extract inhibited formation of sickle cells under severe hypoxia, with only $0-5 \%$ sickle cells at 40 min compared with untreated SS cell suspensions which had over $60 \%$ sickle cells. The amino acids, phenylalanine, tyrosine and glycine already reported in the unripe fruit of Carica papaya, which are the possible antisickling components and responsible for their antisickling activity [53].

\section{h. Antioxidant Activity}

The antioxidant activity has been reported by Srikanth et al. [56] In this study, the free radical scavenging activity of the aqueous leaf extraction of C. papaya was studied by using different antioxidant models of screening e.g lipid peroxide (rat brain and liver), 1,1-diphenyle hydrazyl (DPPH),2,2- azinobis -(3-ethyle benzothiazoline -6-sulphonate) (ABTS), nitric oxide, super oxide and hydroxyl radical model. The extract showed good dose dependent free radical scavenging activity in all the in vitro models. IC50 values were found to be 198,141,185,244, 323, 461 and $922 \mu \mathrm{g} / \mathrm{ml}$ respectively in DPPH, ABTS, nitric oxide, superoxide, hydroxyl ion, lipid peroxidation (liver and brain) inhibition assays. However the extract showed only moderate scavenging activity of hydroxyl radical and anti-lipid peroxidation potential, which was performed using rat liver and brain homogenate.

The antioxidant results revealed that the extract of unripe pawpaw peel had higher ferric reducing antioxidant property $(112.35 \mathrm{mg}$ AAE/100g) compared to the unripe papaya seed extract (102.78 mg AAE/100 g) [57]. In papaya peel, highest TPC and reducing activity was shown by water extract while, TFC and radical scavenging activity was given by $80 \%$ ethanolic extract [53].

\section{i. Antimalarial Activity}

Bhat and Surolia [58] reported the petroleum ether extract of the rind of raw papaya fruit exhibits significant antimalarial activity. There may be significant commercial potential in extracting the active element from this plant, which grows abundantly throughout the tropics and the rind of which is discarded as waste, can be exploited for antimalarial activity. In another study, C. papaya extracts showed moderate to good antiparasitic effects. These four concentrations $(25,50,100$ and $150 \mu \mathrm{g} / \mathrm{mL}$ ) of ethanol leaf extracts exhibited promising inhibitory activity against the CQ sensitive strain with (IC50) values 40.75\%, 36.54\%, 25.30\%, and $18.0 \%$ and in CQ resistant $50.23 \%, 32.50 \%, 21.45 \%$, and $23.12 \%$ against P. falciparum [30].

\section{j. Anti-tumor Activity}

Nariko et al. [59] reported that aqueous extract of C. papaya leaves exhibits anti-tumor activity and it has been reported. In PBMC, the production of $\mathrm{IL}-2$ and $\mathrm{IL}-4$ was reduced following the addition of $\mathrm{C}$. papaya extract, where as that of IL-12p40, IL-12p70, IFN- $\gamma$ and TNF- $\alpha$ was enhanced without growth inhibition.

\section{k. Antihyperlipedimic}

The antihyperlipedimic activity of ethanol root extract of C. papaya was demonstrated in wistar rats. The results of this study suggested that (ERCP) possessed potent anti-hyperlipidemic activity. In poloxamer-407 induced hyperlipidemia In Wistar rats, as was evident from the reduced levels of TC, TG, LDL and VLDL [60]. 


\section{Anti-helminthic Activity}

Satrija et al. [61] indicated that the latex of this species has anthelmintic efficacy against Heligmosomoides polygyrus in experimentally infected mice, which suggests its potential role as an anthelmintic against potent intestinal nematodes of mammalian hosts. It also has anthelmintic activity against natural infection of Ascaris suum in pigs and found to be $100 \%$ effective at the dose of $8 \mathrm{~g} / \mathrm{kg}$ body weight [62]. Another study indicates that the plant extracts of papaya possesses a dose dependent significant effect on the egg, infective larvae and adult worms of Trichostrongylus colubriformis. Alcoholic extracts of papaya shows potential in vitro antiparasitic action, which affects eggs, infective larvae and adult Haemonchus contortus [63].

By combining C. papaya with Anthocleista schweinfurtii, we can formulate an antisickling polyherbal drug which can be fortified with Moringa oleifera to manage sickle cell anemia and malnutrition $[64,65]$.

\section{Conclusion}

The African tropical region is characterized by the endemicity of many diseases for which population face many difficult to access to conventional medicines. It is therefore important to search for alternative solutions, especially from medicinal plant species. The aim of this study was to do bibliographic research on the bioactivity and phytochemistry of Carica papaya. The results revealed that this plant species possesses various pharmacological properties (like anti-oxidant, anti-inflammatory, antibacterial) which can be useful in the management of Sickle cell disease.

\section{References}

1. Farnsworth, N.R. (1990). The Role of Ethno Pharmacology in Drug Development. Ciba Foundation Symposium 154. Bioactive Compounds from Plants. John Wiley \& Sons, Baffins Lane, Chichester (England)., 2-21.

2. Arun, K.S., Vinay, K.S. (2016). Carica Papaya- A Herbal Medicine. International Journal of Research Studies in Biosciences (IJRSB), 4(11), 19-25.

3. Bongo, G.N., Inkoto, C., Masengo, C.A., Tshiama C., Lengbiye E., Djolu R., Mutwale K., Ngombe K., Mbemba T., Tshilanda D., Mpiana, P.T., Ngbolua, K.N. (2017). Antisickling, antioxidant and antibacterial activities of Afromomum alboviolaceum (Ridley) K. Schum, Annona senegalensis Pers. and Mondia whitei (Hook. f.) Skeels. American Journal of Laboratory Medicine, 2(4), 52-59.

4. Inkoto, C.L., Bongo, G.N., Kapepula, P.M., Masengo, C.A., Gbolo, B.Z., Tshiama, C., Ngombe, N.B., Iteku, J.B., Mbemba, T., Mpiana, P., Ngbolua, K.N. (2017). Microscopic and phytochemical assays of selected Congolese medicinal plants: Aframomum alboviolaceum (Ridley) K. Schum, Annona senegalensis Pers. and Mondia whitei (Hook.f.) Skeels. Emer Life Sci Res., 3(1), 1-10.

5. Ngbolua, K.N., Inkoto, C.L., Mongo, N.L., Ashande, C.M., Masens, Y.B., Mpiana, P.T. (2019). Étude ethnobotanique et floristique de quelques plantes médicinales commercialisées à Kinshasa, République Démocratique du Congo. Rev. Mar. Sci. Agron. Vét., 7(1), 118-128

6. Ngbolua, K.N., Lufuluabo, G.L., Lengbiye, E.M., Bongo, G.N., Inkoto, C.L, Masengo, C.A., Songowe, B.S., Gbolo, B.Z., Mpiana, P.T. (2017). A review on the Phytochemistry and Pharmacology of Psidium guajava L. (Myrtaceae) and Future direction. Discovery Phytomedicine, 5(1), 7-13.

7. Iteku, J.B., Mbayi, O., Bongo, G.N., Mutwale, P.K., Wambale, J.M., Lengbiye, E., Inkoto, 
C.L., S.N. Ngunde, S.N., Ngbolua, K.N. (2019). Phytochemical Analysis and Assessment of Antibacterial and Antioxidant Activities of Phytolacca dodecandra L. Herit Leaf Extracts (Phytolaccaceae). International Journal of Biomedical Engineering and Clinical Science, 5(3), 31-39.

8. Tshilanda, D.D., Inkoto, C.L., Mpongu, K., Mata, Z., Kapepula, P.M., Tshibangu, D.S.-T., Bongo, G.N., Ngbolua, K.N., Mpiana, P.T. (2019). Microscopic Studies, Phytochemical and Biological Screenings of Ocimum canum. International Journal of Pharmacy and Chemistry, 5(5), 61-67.

9. Nkasa, H.L., Inkoto, C.L., Muzomwe, J.-C.M., Masengo, E.I., Muzomwe, C.M., Mulenga, C.M., Taba, K.M. (2020). Phytochemical screening and antibacterial activity of phytomedecine mathesia, a drug use against buruli ulcer in republic democratic of the Congo (drc). Ejpmr., 7(2), 52-56

10. El Moussaoui, A., Nijs, M., Paul, C., Wintjens, R., Vincentelli, J., Azarkan, M., Looze, Y. (2001). Revisiting the enzymes stored in the laticifers of Carica papaya in the context of their possible participation in the plant defence mechanism. Cell. Mol. Life Sci., 58, 556570.

11. Krishna, K.L., Paridhavi, M., Patel, J.A. (2008). Review on nutritional, medicinal and pharmacological properties of Papaya (Carica papaya Linn.). Nat. Prod. Radiance, 7, 364373.

12. Eke, O.N., Augustine, A.U., Ibrahim, H.F. (2014). Qualitative Analysis of Phytochemicals and Antibacterial Screening of Extracts of Carica papayaFruitsand Seeds. Int. J. Modern Chem., 6(1), 48-56.

13. Imaga, N.O.A., Gbenle, G.O., Okochi, V.I., Akanbi, S.O., Edeoghon, S.O., Oigbochie, V., Kehinde, M.O., Bamiro, S.B. (2009). Antisickling property of Carica papaya leaf extract. Afr. J. Biochem. Res., 3(4), 102-106.

14. Ayoola, P.B., Adeyeye, A. (2010). Phytochemical and nutrient evaluation of carica papaya (pawpaw) leaves. IJRRAS., 5 (3), 325-328

15. Baskaran, C., Ratha, B.V., Velu, S., Kumaran, K. (2012). The efficacy of Carica papaya leaf extract on some bacterial and a fungal strain by well diffusion method. C. Asian Paicfic Journal of Tropical Disease., 2(2), S658-S662

16. Bergonio, K.B., Perez, M.A. (2016). The potential of male papaya (Carica apapaya L.) flower as a functional ingredient for herbal tea production. India Journal of Traditioal Knowledge., 15(1), 41-49.

17. Sreenivasan, S., Vello, S., Naidu, R.J., Lachimanan, Y.L. (2011). Antihyperglycaemic effects of ethanol extracts of Carica papaya and Pandanus amaryfollius leaf in streptozotocininduced diabetic mice. Natural Product Research, 25(20), 1982-1987.

18. Kusum, S., Rashmi, T., Hari, P.D., Khem, R.J. (2019). Phytochemical Screening, Free Radical Scavenging and -Amylase Inhibitory Activities of Selected Medicinal Plants from Western Nepal. Medicines, 6(2), 2-9.

19. Ankit N., Devendrasinh, J. (2017). Pharmacognostic study of carica papaya leaf extract as inhibitors of reactive oxygen species. Int. Res. J. Pharm., 8(3), 13-17.

20. Asha, R., Navneet, K.V., Anubha, G. (2014). A Brief Study on Carica Papaya- A Review. IJCTPR, 2(4), 541-550

21. http://www.ethnoleaflets.com/leaflets/papaya.htm

22. Roa-de la Fuente, L.F., Lobato-García, C.E., Blé-Castillo, J.L., López-Meraz, L., DíazZagoya, J.C., Bermúdez-Ocaña D.Y. (2014). Phytochemical screening and hypoglycemic activity of Carica papaya leaf in streptozotocin-induced diabetic rats. Rev Bras Farmacogn, 24(4), 341-347.

23. Caninia, A., Alesiani, D., D’Arcangelo, G., Tagliatesta, P. (2007). Gas chromatography-mass spectrometry analysis of phenolic compounds from Carica papaya L. leaf. Journal of 
Food Composition and Analysis, 20(7), 584-590.

24. Thao, T.T.N., Paul, N.S., Marie-Odile, P., Amitha, K.H. (2012). Anticancer activity of Carica papaya: A review. Mol. Nutr. Food Res, 57, 153-164.

25. Saran, P.L., Choudhavy, R., Solanki, I.S., Devi, G. (2015).Traditional medicants through papaya in North eastern plains zones of India. India J Tradit Knowle., 15(4), 537-543.

26. King, B.B., Milagros, AP. (2015). The potential of male papaya (Carica papaya, L.) flower as a functional ingredient for herbal tea production. India journal of Traditional knowledge, 15(1), 41-49.

27. Amenta, R., Camarda, L., Di Stefano, V., Lentini, F. et al. (, 2000). Traditional medicine as a source of new therapeutic agents against psoriasis. Fitoterapia, 71, S13-S20.

28. Hewitt, H., Whittle, S., Lopez, S., Bailey, E. et al. (2000). Topical use of papaya in chronic skin ulcer therapy in Jamaica. West Indian Med. J., 49: 32-33.

29. Otsuki, N., Dang, N.H., Kumagai, E., Kondo, A. et al. (2010). Aqueous extract of Carica papaya leaves exhibits anti-tumor activity and immunomodulatory effects. J. Ethnopharmacol, 127, 760-767.

30. Kovendan K., Murugan K., Kumar, A.N., Savariar V., Hwang, J.-S. (2011). Bio efficacy of larvicdial and pupicidal properties of Carica papaya (Caricaceae) leaf extract and bacterial insecticide, spinosad, against chikungunya vector, Aedes aegypti (Diptera: Culicidae). Parasitol Res, 110(1), 669-678.

31. Banala, R.R., Nagati, V.B., Karnati, P.R. (2015). Green synthesis and characterization of Carica papaya leaf extract coated silver nanoparticles through X-ray diffraction, electron microscopy and evaluation of bactericidal properties. Saudi Journal of Biological Sciences, 22(5), 637-644.

32. Indran, M., Mahmood, A.A., Kuppusamy, U.R. (2008). Protective Effect of Carica papayaL Leaf Extract against Alcohol Induced AcuteGastric Damage and Blood Oxidative Stress in Rats. West Indian Med J., 57(4), 323.

33. Yahaya, A., Ali, M., Idris, A. (2017). Antibacterial Activity and Phytochemical Screening of Carica papaya on some Enteric Bacterial Isolates of Public Health Importance. Greener Journal of Biological Sciences, 7(1), 001-007.

34. Owoyele, B.V., Adebukola, O.M., Funmilayo, A.A., Soladoye, O. (2008). Anti-inflammatory activities of ethanolic extract of Carica papayaleaves. Inflammopharmacology, 16(8), 168 173.

35. Doughari, J.H., Elmahmood, A.M., Manzara, S. (2007). Studies on the antibacterial activity of root extracts of Carica papaya L. Afr. J. Microbiol. Res., 5(2), 7-41.

36. Prashant, T., Kuldeep, K., Rajnikant, P., Alok, P., Ashish, P., Pratap, K.S. (2011). Evaluation of aqueous extract of Roots of Carica papaya on wound healing activity in albino Rats. . Chem. Pharm. Res., 3(4), 291-295

37. Ezekwe, A.S., Chikezie, C.P. (2017). GC-MS Analysis, Hypoglycemic Activity of Aqueous Root Extract of Carica papaya and Its Effects on Blood Lipid Profile and Hepatorenal TissuesBiomarkers of Diabetic Rats. J Diabetes Metab., 8(5):1-9.

38. Sarmaa, H.N., Mahanta, H.C. (2000). Modulation of morphological changes of endometrial surfaceepithelium by administration of composite root extract in albino rat. Contraception, 62(2), 51-54

39. Adeneye, A.A., Olagunju, J.A., Banjo, A.A.F., Abdul, S.F., Sanusi, O.A., Sanni, O.O., Osarodion, B.A., Shonoiki, O.E. (2009). The Aqueous Seed Extract of Carica papaya Linn. Prevents Carbon Tetrachloride Induced Hepatotoxicity In Rats. International Journal of Applied Research in Natural Products, 2(2), 19-32.

40. Kermanshai, R., McCarry, E.B., Rosenfeld, J., Summers, SP., Weretilnyk, A.E., Sorgera, JG. (2001). Benzyl isothiocyanate is the chief or sole anthelmintic inpapaya seed extracts. Phytochemistry., 57(3), 427-435. 
41. Okeniyi, A.O.J., Tinuade, A.O., Oyeku, A.O., Lateef, A.A. (2007). Effectiveness of Dried Carica papaya Seeds Against Human Intestinal Parasitosis: A Pilot Study. J Med Food, 10(1), 194-196.

42. Nirmal, K.L., Lalit, K.K., Manivannan, B., Pradyumna, K.M., Neelam, P. (2000). Human sperm immobilization effect of Carica papaya seed extracts: an in vitro study. Asian J Androl., 2(1), 103-109

43. Lohiya, N.K., Manivannan, B., Mishra, P.K., Pathak, N., Sriram, S.S., Bhande, S., Panneerdos S. (2002). Chloroform extract of carica papaya seeds induces long-term reversible azoospermia in langur monkey. Asia J Androl, 4(1), 17-26.

44. Vijay, K., Sriram, S. (2010). Antioxidant activity of seedextracts ofAnnona squamosaandCarica papaya. Nutrition \& Food Science, 40(4), 403-408.

45. Yee, K.A., Winne, C.M.S., Hock, E.K., Seng, Y.H. (2012). Antioxidant Potential of Carica Papaya Peel and Seed. Focusing on Modern Food Industry, 1(1), 11-16.

46. Preetee, J., Singh, D.K. (2008). Molluscicidal activity of Carica papaya and Areca catechu against the freshwater snail Lymnaea acuminate. Veterinary Parasitology, 152(3-4), 264270

47. Kadry, M.S. (2012). Antioxidant and immunostimulant effect of Carica papaya linn. aqueous extract in acrylamide intoxicated rats. Acta Inform Med, 20(3), 180-185.

48. Quintal, C.P., Gonzalez, F.T., Buenfil, I.R., Gallegos, T.S. (2011). Antifungal Activity in Ethanolic Extracts ofCarica papayaL. cv.Maradol Leaves and Seeds. Indian J Microbiol, 51(1), 54-60.

49. Balasubramanian, R., Balasundaram, J., Subramanian, K., Narayanan, M. (2002). Effect of Dried Fruits of Carica papayaLINNon Hepatotoxicity. Biol. Pharm. Bull., 25(12), 1645 1646.

50. Sabaa, T.M., Sahar, A.H.A.L.-S., Nidaa, M. (2014). Antiparasitic activity of Natural Plant Carica papaya Seed Extract against Gastrointestinal Parasite Entamoeba histolytica. International Journal of Innovation and Applied Studies, 7(1), 58-64.

51. Okewumi, T.A., Oyeyemi, A.W. (2012). Gastro-protective activity of aqueous Carica papaya seed extract on ethanol induced gastric ulcer in male rats. Afr. J. Biotechnol, 11(34), 86128615

52. Jyotsna, K.P., Yashab, K., Priyanka, P. (2014). Antibacterial Activity of Seed and Leaf Extract of Carica Papayavar. Pusa dwarf Linn. IOSR-JPBS, 9(2), 29-37

53. Sarmad, S., Shamsa, N., Faqir, M., Bushra, A., Bilal, A. (2017). Phytochemical screening and in-vitro evaluation of pharmacological activities of peels of Musa sapientum and Carica papaya fruit. Natural Product Research, 32(11), 1333-1336.

54. Sobia, K., Javaid, M.A., Ahmad, M.S., Rehmatullah, Q., Hina, G., Iram, B., Pervaiz, A., Farhana, B., Nyla, J., Gulfraz, M. (2016). Assessments of phytochemicals and hypoglycemic activity of leaves extractsofcarica papayain diabetic mice. Sobiaetal., IJPSR, 7(9), 1000-08.

55. Umana, U.E., Timbuak, J.A., Danladi, J., Samuel, A., Hambolu, J., Anuka, J.A. (2014). Antiinflammatory, antipyretic and antinociceptive activities of Orally Administered Aqueous Extract of Carica papaya Seeds in Animal Models. Ann. Exp. Bio., 2 (4), 21 -27.

56. Srikanth, G., Babu, S.M., Kavitha, C.H.N., Rao, M.E.B., Vijaykumar, N., (2010). Pradeep. Studies on in-vitro antioxidant activities of Carica papaya aqueous leaf extract. Research Journal of Pharmaceutical Biological and Chemical Sciences, 1(2), 59-65.

57. Abayomi, D.F., Ozioma, N.F., Micheal, E.A., Idowu, O.S., Bola, A.V. (2016). Phytochemical and antioxidant analysis of aqueous extracts of unripe pawpaw (carica papaya Linn.) fruit's peel and seed. IJRRAS, 27(3), 68-71.

58. Bhat, P.G., Surolia N. (2001). In vitro Antimalarial activity of extracts of three plants used in the traditional medicine of India, Am J Trop Med Hyg, 65(4), 304-308 
59. Noriko, O., Nam, H.D., Emi, K., Akira, K., Satoshi, I., Chikao, M. (2010). Aqueous extract of Carica papaya leaves exhibits anti-tumor activity and immunomodulatory effects. Journal of Ethnopharmacology, 127( 3), 760-767

60. Venkateswaran V., Rafeeka, A.R.R.S.S., Sambathkuma, R. (2017). Evaluation of Antihyperlipidemic Activity of Ethanolic Root Extract of Carica Papaya in Poloxamer 407 Induced Hyperlipidemia in Wistar Rats. Am. J. PharmTechRes, 7(6), 35-43

61. Satrija F., Nansen P., Murtini S., He S. (1995). Anthelmintic activity of papaya latex against Heligmosomoides polygyrus infections in mice, J Ethnopharmacol, 48(3), 161-164.

62. Satrija F., Nansen P., Bjorn H., Murtini S., He, S. (1994). Effect of papaya latex against Ascaris suum in naturally infected pigs, J Helminthol, 68(4), 343-346.

63. Hounzangbe-Adote S., Fouraste I., Moutairou K., Hoste, H. (2005). In vitro effects of four tropical plants on the activity and development of the parasitic nematode, Trichostrongylus colubriformis, J Helminthol, 79(1), 29-33.

64. Ngunde-te-Ngunde, S., Lengbiye, M.E., Tshidibi, D.J., Kengo, V.F., Djolu, D.J., Masengo, A.C., Gbolo, Z.B., Iteku, B.J., Mpiana, P.T., Ngbolua, K.N. (2019). Antisickling and Antibacterial Activites of Anthocleista schweinfurthii Gilg. (Gentianaceae) from Nonhuman Primates Pharmacopoeia in Democratic Republic of the Congo. Budapest International Research in Exact Sciences, 1(3), 14-20.

65. Randrantoarimbola L., Rafalimanantsoa J., Ratiarimananjatovo N., Randriamanantena A.A., Bongo N., Ngbolua K.N., Robijaona B. (2020). Formulation of Moringa oleifera Lam. based Bio-fortified Food Supplement for Pregnant Women in Madagascar, Indian Ocean. Britain International of Exact Sciences (BIoEx) Journal, 2(2), 533-540. 